\title{
19. BENTHIC AND PLANKTONIC FORAMINIFERS, AND STABLE ISOTOPIC ANALYSIS OF MASS-FLOW SEDIMENTS IN THE AMAZON FAN ${ }^{1}$
}

\author{
Claudia Gutterres Vilela² and Mark Maslin ${ }^{3}$
}

\begin{abstract}
Amazon Fan deep mass-transport deposits (MTDs) were analyzed to investigate their dynamic nature, in particular their sediment sources. We have analyzed both the benthic foraminiferal assemblages and the stable isotopic composition of benthic and planktonic foraminifers from sediments recovered during Ocean Drilling Program Leg 155. Samples studied came from Sites 936 and 933, which were located in $\sim 3300 \mathrm{~m}$ of water depth. The MTDs are referred to, respectively, as Unit R and the deep Eastern Mass-transport Deposit (EMTD). These units are situated at more than $100 \mathrm{~m}$ below the sediment/water interface, constituting $\sim 50 \mathrm{~m}$ (Site 933) and $150 \mathrm{~m}$ (Site 936) of thickness.

Stable isotope records and foraminiferal assemblages suggest that there are distinct blocks in the MTDs, with inclusion of interglacial material in the base of the deep EMTD. The majority of sediments in the MTDs were formed during early oxygen Stage 3 (or another early glacial period), or there has been significant mixing of interglacial and glacial material within the separate blocks.

In the benthic foraminiferal assemblage, the dominance of buliminids, which are infaunal deposit feeders, suggests that the MTDs originated from bathyal environments. Sparse occurrences of characteristic species indicate that the continental shelf is another sediment source. Further details were obtained by comparing the Holocene benthic foraminiferal microfauna from samples collected on the Amazon shelf and slope, as well as with pelagic and last glacial maximum sediments, collected from the Amazon deep sea. The different assemblages found in both abyssal and MTDs demonstrate a distinct origin for the latter. Buliminids and uvigerinids, which are common on the Amazon continental slope, were found in the MTDs. Globocassidulina subglobosa and Cassidulina laevigata are common on the upper slope and were also encountered in the MTDs. Species like Quinqueloculina sp. A and Pseudononion atlanticum, which are present on the Amazon shelf, were also encountered in the MTDs.

In the deep EMTD, a Bulimina dominated assemblage suggests an upper/middle bathyal environment, whereas samples dominated by Brizalina aenariensis suggest a source from shelf environments. In Unit $\mathrm{R}$, the pattern is similar, with the presence of the Bulimina assemblage and dominance of Brizalina aenariensis in the top of the unit.
\end{abstract}

\section{INTRODUCTION}

The Amazon Fan has developed since the Andean uplift in the late Miocene, due to Amazon River sediment discharge, which is the major source of terrigenous sediments to the Equatorial Atlantic (Hoorn et al., 1995). At the present high sea-level stand and during previous interglacials, the sediments from the Amazon River are prevented from crossing the shelf, so the fan has been inactive during the Holocene. During high sea-level stands, terrigenous sediments are discharged onto the inner continental shelf and are trapped on the shelf. While the fan is inactive, all terrigenous sediments stay on the shelf, and only pelagic sediments are deposited on the Amazon Fan. During low sea-level stands, in glacial periods, sediments from the Amazon River were discharged into the Amazon Canyon and were transported directly to the Amazon cone (Damuth and Kumar, 1975). The drop in sea level may also destabilize the shelf sediments causing slumps and other gravity flows.

In the Amazon Fan, sediments of mass-transport origin lie on both sides of the active channel, and are overlain by thin Holocene sections of pelagic foraminiferal ooze and hemipelagic clay of latest Wisconsin age (Damuth and Embley, 1981). During Ocean Drilling Program (ODP) Leg 155, older mass-transport deposits (MTDs) were

'Flood, R.D., Piper, D.J.W., Klaus, A., and Peterson, L.C. (Eds.), 1997. Proc. ODP, Sci. Results, 155: College Station, TX (Ocean Drilling Program).

${ }^{2}$ Departamento de Geologia, Universidade Federal do Rio de Janeiro IGEO/CCMN, Ilha do Fundão, 21949-900 Rio de Janeiro, RJ, Brasil. vilela@igeo.ufrj.br

${ }^{3}$ Environmental Change Research Centre, Department of Geography, University College London, 26 Bedford Way, London, WC1H OAP, United Kingdom. penetrated at several different sites. These sediments occur intercalated with channel/levee complexes (Piper et al., Chapter 6, this volume). The debris-flow samples analyzed here are referred to as Unit $\mathrm{R}$, which underlies the Upper Levee Complex and represents the oxygen isotope Stages 2-4, and as the deep Eastern Mass-transport Deposit (EMTD), which overlies the crest of the Lower Levee Complex and corresponds in age to isotope Stage 7 (Maslin and Mikkelsen, this volume). They were recovered at Sites 936 and 933, respectively (Fig. 1). Both sites were located in $\sim 3300 \mathrm{~m}$ of water depth. The MTDs are situated at more than $100 \mathrm{~m}$ below the sediment/water interface, constituting $\sim 50 \mathrm{~m}$ (Site 933) and $150 \mathrm{~m}$ (Site 936) of thickness.

To investigate the dynamic nature of the Amazon Fan deep MTDs, in particular their sediment sources, we have analyzed both the benthic foraminifer assemblages and the stable isotopic compositions of benthic and planktonic foraminifers. Quantitative data like abundance and diversity, as well as dominance indexes of selected species, were evaluated. Morphogroups, based on test adaptations to habitat and feeding strategies, were also determined. These quantitative and ecologic parameters enable us to estimate the original paleobathymetry and marine environment of these deposits. Comparisons of these data with a detailed study of recent benthic foraminifer contents of the Amazon shelf (Vilela, 1995) and continental slope enable us to estimate the origin location of some of the sediment packages within the debris flows. Likewise, data were compared with Holocene pelagic and hemipelagic sediments collected in the Amazon Fan.

It is also important to determine whether the MTDs are made up of predominantly glacial, interglacial sediments, or a mixture of both. 
Figure 1. Location of sites from ODP Leg 155 in the Amazon Fan. Arrows indicate Sites 933 and 936 (modified from Flood et al., 1995; Damuth et. al., 1988; and Manley and Flood, 1988).

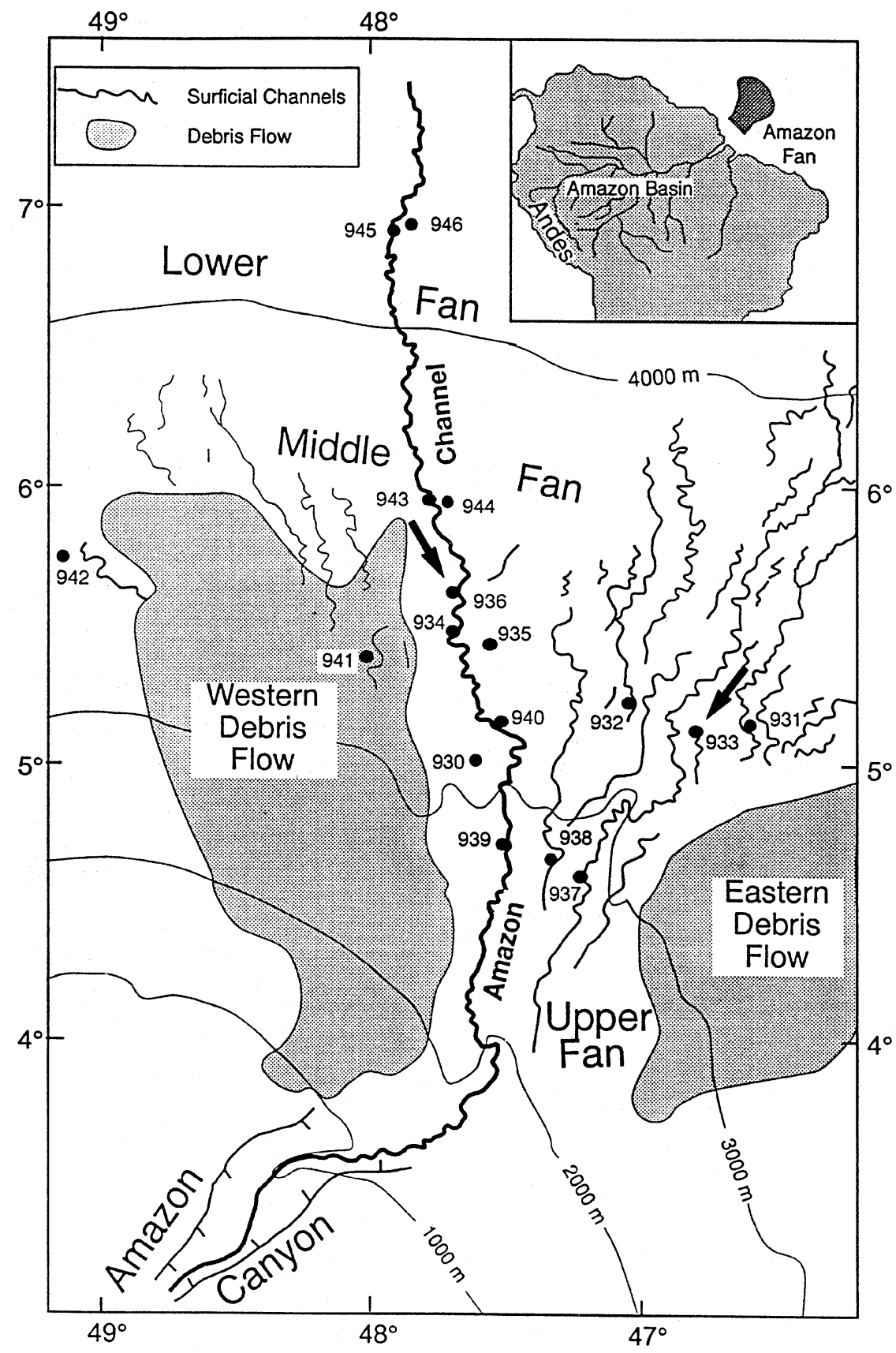

By using stable isotopic measurements from both benthic and planktonic foraminifers, we can determine the climatic conditions at the time when they were originally laid down.

\section{METHODS}

\section{Benthic Foraminifers}

Subsamples were analyzed every $10 \mathrm{~m}$ throughout the MTDs in Holes 936A and 933A. The samples in Hole 936A were washed and sieved at $62 \mu \mathrm{m}$, and then dried at $50^{\circ} \mathrm{C}$. The samples were then drysieved at $125 \mu \mathrm{m}$ and the benthic foraminifer species from both fractions were identified under a binocular microscope. Because of the very low numbers of specimens found in the $10-\mathrm{cm}^{3}$ samples of Hole 936A, samples from Hole 933A were further sieved and counted at the $>44-\mu \mathrm{m}$ fraction. However, the $>44-\mu \mathrm{m},<62-\mu \mathrm{m}$ fraction from
Hole 933A did not present satisfactory results, because many of the small and juvenile specimens were difficult to identify.

Two subsamples of $10 \mathrm{~cm}^{3}$ at 0.21 and at $5.90 \mathrm{mbsf}$ (meters below seafloor) in Hole 933A were analyzed. They have been dated, respectively, as Holocene pelagic sediments and last glacial maximum (LGM) hemipelagic sediments. They were washed through a $62-\mu \mathrm{m}$ mesh sieve, dried, and picked.

All individuals were counted and classified at the species level, based on the literature. Photomicrographs of selected species were taken with a Zeiss DSM940A scanning electron microscope (SEM), using a Contax 35-mm camera.

\section{Stable Isotopes}

The oxygen and carbon stable isotope compositions of the benthic and planktonic foraminifers were measured. The samples were 
freeze-dried and then wet-sieved through a $63-\mu \mathrm{m}$ mesh sieve. The samples were then dry-sieved at convenient intervals between 250 and $400 \mu \mathrm{m}$, from which the foraminifers were picked. Two benthic species were selected for analysis: Cibicides wuellerstorfi and Uvigerina sp. (Table 1). The isotope analyses were performed in the Kiel laboratories, using a Finnigan MAT 251 mass spectrometer. The Kiel system uses a Carbo-Kiel preparation line that is an automated system where acid is added to individual samples and reacted at $90^{\circ} \mathrm{C}$. The analytical reproducibility based upon replicate measurements on an internal laboratory standard is \pm 0.04 for carbon isotopes and \pm 0.07 for oxygen isotopes. In many cases where the sedimentation rate was so high that only one specimen was measured, the gas pressure from the mass spectrometer was checked to be sure there was sufficient material for a reliable estimate. The laboratory isotope results are calibrated to the Peedee belemnite (PDB) scale via the National Bureau of Standards (NBS) 19 standard. Six planktonic foraminifer species were analyzed: Globigerinoides ruber, Globigerinoides trilobus, Globigerinoides sacculifer, Neogloboquadrina dutertrei, Pulleniatina obliquiloculata, and Globorotalia truncatulinoides. The number of each species found at each sample depth varied greatly because of the dilution owing to large charges in sedimentation rate. In cases with low numbers of specimens (no sample of less than six specimens was measured), the gas pressure from the mass spectrometer was noted to make sure there was sufficient material for a reliable estimate. It should be noted that both variations in the number of planktonic foraminifers per sample and a low number of specimens per sample can be major sources for errors (Trauth, 1995). At sedimentation rates of the Amazon Fan, which can exceed $1 \mathrm{~m} / 1000 \mathrm{yr}$, however, the bioturbation component of these errors is reduced. These possible errors were considered when the isotope records were interpreted.

\section{Planktonic Foraminifers}

Samples were prepared according to the degree of lithification. Unlithified ooze was washed with tap water over a $63-\mu \mathrm{m}$ mesh sieve. Samples with cohesive lumps were soaked in a weak solution of Calgon, and then gently stirred in a beaker with a magnetic stirrer, and washed with warm water over a $63-\mu \mathrm{m}$ mesh sieve. Samples were air-dried at $65^{\circ} \mathrm{C}$ in an oven. Preservation in the $>150-\mu \mathrm{m}$ size fraction was estimated from a visual examination of the dried sample. The planktonic foraminifer species were quantified according to the following:

$$
\begin{aligned}
& \mathrm{A}=\text { abundant }(>30 \%), \\
& \mathrm{C}=\text { common }(15 \%-30 \%), \\
& \mathrm{F}=\text { few }(3 \%-15 \%), \\
& \mathrm{R}=\text { rare }(<3 \% \text { to }>0 \%), \text { and } \\
& \mathrm{B}=\text { barren. }
\end{aligned}
$$

When uninterrupted sediment units were recovered, it was possible to use the sequential stratigraphy of the Ericson Zones (Ericson and Wollin, 1956; Ericson et al., 1961). This is based on the appearance of the Globorotalia menardii-complex ( $G$. menardii and/or Globorotalia tumida) during interglacials and the absence of it during the glacials. Due to the very young age of the Amazon Fan sediments recovered during Leg 155, the primary use of planktonic foraminifer assemblages was to differentiate glacial from interglacial sediments, using the G. menardii-complex as a signal of interglacial sediments. The youngest true Atlantic Ocean planktonic foraminifer datum is the last appearance of Globorotalia tosaensis at $0.6 \mathrm{Ma}$; however, this was not found in any of the sediments recovered on Leg 155, including the MTDs. One abundance shift datum that has been shown to be reliable, apart from the Ericson Zones, is the disappearance of P.obliquiloculata at $\sim 40 \mathrm{ka}$ (this is given the abbreviation $\mathrm{Y}_{\text {p.obliq. }}$ ). For each site, every core catcher and a number of other samples were investigated aboard ship (Flood, Piper, Klaus, et al., 1995), providing an overall stratigraphy for Leg 155 (Mikkelsen and Maslin, this volume).

\section{PLANKTONIC FORAMINIFER ASSEMBLAGE RESULTS}

The planktonic foraminifer assemblage data can help define the types of sediment above and below, as well as within the MTDs. The planktonic foraminifer assemblage data indicate that below both the Unit R and the deep EMTD are interglacial units (Flood, Piper, Klaus, et al., 1995). In the case of the deep EMTD (Sites 931 and 933), the debris-flow material sits directly on the interglacial sediments. In contrast, there are levee mud sands, and in some cases, sandy units, between the Unit R MTD and the interglacial sediments. Using nannofossil assemblages, Maslin and Mikkelsen (this volume) have correlated the base of the deep MTDs to different oxygen isotope stages (Fig. 2).

In the deep EMTD, the planktonic foraminifer assemblages at Sites 933 (Fig. 2) and 931 (Flood, Piper, Klaus, et al., 1995; fig. 14, p. 144) indicate that the top of the debris flow contains sediment that was originally formed during a peak glacial period, as both $P$. obliquiloculata and the G. menardii-complex are absent. In the lower half of the deep EMTD, P. obliquiloculata are abundant, whereas the G. menardii-complex is still absent, suggesting a shift to at least a significant sediment contribution from material of early glacial age. This is assumed because $P$. obliquiloculata is indicative of interglacial and early glacial sediments, where as the G. menardii-complex is indicative of full interglacial conditions (Ericson and Wollin, 1956, 1968; Ericson et al., 1961). Near the base of the deep EMTD, G. tumida appears, suggesting either a separate distal interglacial sediment source or a reworking of the underlying interglacial material up into the MTD. This biostratigraphic evidence supports the sedimentary evidence that the MTDs have distinct subunits or blocks within them. Unfortunately, this could imply both multiple events or a single event with multiple blocks from various sources (Piper et al., Chapter 6, this volume).

In contrast, the Unit R MTD has different foraminifer assemblages at Site 936 (Fig. 3) compared with those at Site 935 (Flood, Piper, Klaus, et al., 1995; fig. 17, p. 289) and Site 944 (Flood, Piper, Klaus, et al., 1995; fig. 15, p. 608). Another difference between Unit R and the deep EMTD is that at each site, the planktonic foraminifer assemblage in Unit $\mathrm{R}$ is consistent throughout the sequence. At Sites 935 and 944, the Unit R MTD contains the G. menardii-complex and $P$. oliquiloculata suggesting a significant sediment input from interglacial and early glacial material. However, at Site 936, the G. menardiicomplex is absent, although $P$. oliquiloculata is present, suggesting an early glacial sediment source. It can thus be postulated that a single MTD may contain very different aged sediment across a distance of less than $15 \mathrm{~km}$ (the distance between Sites 935 and 936).

Another consideration is the age of the sediment directly above the MTDs, which indicates the youngest age at which the MTDs could have been formed. The paleomagnetic Lake Mungo Excursion (Cisowski and Hall, this volume) is detected above the deep EMTD in Sites 931 and 933, making the MTD older than $32 \mathrm{ka}$. The absence of both the G. menardii complex and P. obliquiloculata in the foraminifer assemblages of the intervening sediment between the paleomagnetic Lake Mungo Excursion and the top of the MTD suggests the MTD may be younger than $40 \mathrm{ka}$. Assuming, therefore, that the foraminifer assemblages are complete, despite the low abundances, then the deep EMTD was last active between 30 and $40 \mathrm{ka}$.

The Unit R MTD is harder to date as there are significant high amplitude reflection packet (HARP; nearly parallel, horizontal reflections) units above the MTD. Consequently, the Lake Mungo Excursion was not detected at any of the three sites. However, at Sites 935 and 936, pockets of hemipelagic sediment were found within the HARP unit. These hemipelagic sequences contained $P$. obliquiloculata, but the G. menardii-complex was absent, dating these sections 
Table 1. Cibicides wuellerstorfi and Uvigerina sp. stable isotope records from Holes 933A and 936A.

\begin{tabular}{|c|c|c|c|c|c|c|}
\hline $\begin{array}{l}\text { Core, section, } \\
\text { interval }(\mathrm{cm})\end{array}$ & $\begin{array}{l}\text { Depth } \\
\text { (mbsf) }\end{array}$ & Species & $\begin{array}{c}\text { No. of } \\
\text { test(s) } \\
\text { measured }\end{array}$ & $\begin{array}{c}\text { Weight of } \\
\text { tests } \\
(\mu \mathrm{g})\end{array}$ & $\delta^{13} \mathrm{C}$ & $\delta^{18} \mathrm{O}$ \\
\hline \multicolumn{7}{|l|}{ 155-933A- } \\
\hline $1 \mathrm{H}-1,115$ & 0.21 & C. wuellerstorfi & 1 & 11.90 & -1.46 & 3.77 \\
\hline $1 \mathrm{H}-1,21$ & 6.40 & C. wuellerstorfi & 2 & 39.40 & 2.17 & 4.03 \\
\hline $2 \mathrm{H}-1,70$ & 6.40 & C. wuellerstorfi & 2 & 25.10 & -1.83 & 3.87 \\
\hline $7 \mathrm{H}-\mathrm{CC}$ & 63.80 & C. wuellerstorf $i$ & 3 & 150.00 & -1.68 & 2.81 \\
\hline $11 \mathrm{X}-\mathrm{CC}$ & 97.52 & C. wuellerstorfi & 3 & 57.30 & -1.96 & 4.91 \\
\hline $12 \mathrm{X}-\mathrm{CC}$ & 103.83 & C. wuellerstorfi & 4 & 109.10 & -1.72 & 4.72 \\
\hline $12 \mathrm{X}-\mathrm{CC}$ & 103.83 & C. wuellerstorf $i$ & 2 & 51.30 & -2.31 & 4.71 \\
\hline $12 \mathrm{X}-\mathrm{CC}$ & 103.83 & C. wuellerstorfi & 4 & 54.90 & -2.28 & 4.73 \\
\hline $18 \mathrm{X}-\mathrm{CC}$ & 160.78 & C. wuellerstorf $i$ & 1 & 35.80 & 1.15 & 4.47 \\
\hline $19 X-1,36$ & 167.56 & C. wuellerstorfi & 2 & 34.60 & -2.05 & 5.14 \\
\hline $19 X-1,58$ & 167.78 & C. wuellerstorfi & 1 & 27.40 & -1.97 & 5.05 \\
\hline $19 X-1,70$ & 167.90 & C. wuellerstorfi & 1 & 9.50 & -2.09 & 4.85 \\
\hline $19 X-2,20$ & 168.27 & C. wuellerstorfi & 1 & 15.50 & -2.17 & 5.06 \\
\hline $19 X-2,97$ & 169.04 & C. wuellerstorfi & 2 & 34.60 & -2.11 & 5.30 \\
\hline $19 \mathrm{X}-2,133$ & 169.50 & C. wuellerstorfi & 1 & 9.50 & -2.20 & 5.28 \\
\hline $1 \mathrm{H}-1,21$ & 0.21 & Uvigerina sp. & 1 & 53.70 & 0.56 & 3.32 \\
\hline $2 \mathrm{H}-1,70$ & 6.40 & Uvigerina sp. & 2 & 27.40 & -2.26 & 5.13 \\
\hline $5 \mathrm{H}-\mathrm{CC}$ & 44.21 & Uvigerina $\mathrm{sp}$. & 2 & 54.50 & -2.59 & 4.97 \\
\hline $5 \mathrm{H}-\mathrm{CC}$ & 44.21 & Uvigerina sp. & 2 & 95.50 & -2.12 & 5.22 \\
\hline $5 \mathrm{H}-\mathrm{CC}$ & 44.21 & Uvigerina $\mathrm{sp}$ & 1 & 63.60 & -2.45 & 5.12 \\
\hline $11 \mathrm{X}-\mathrm{CC}$ & 97.52 & Uvigerina sp. & 3 & 63.60 & -2.06 & 4.69 \\
\hline $11 \mathrm{X}-\mathrm{CC}$ & 97.52 & Uvigerina sp. & 5 & 54.50 & -1.76 & 4.76 \\
\hline $12 \mathrm{X}-\mathrm{CC}$ & 103.83 & Uvigerina sp. & 2 & 32.20 & -1.46 & 4.63 \\
\hline $13 \mathrm{X}-\mathrm{CC}$ & 110.81 & Uvigerina $\mathrm{sp}$. & 1 & 15.50 & -2.72 & 4.25 \\
\hline $18 \mathrm{X}-\mathrm{CC}$ & 160.78 & Uvigerina $\mathrm{sp}$ & 4 & 127.30 & -1.79 & 4.69 \\
\hline $18 \mathrm{X}-\mathrm{CC}$ & 160.78 & Uvigerina sp. & 4 & 68.20 & -1.95 & 4.65 \\
\hline $19 X-1,6$ & 167.26 & Uvigerina sp. & 1 & 26.30 & -1.22 & 4.69 \\
\hline $18 \mathrm{X}-2,120$ & 167.36 & Uvigerina $\mathrm{sp}$ & 2 & 7.20 & -1.09 & 5.64 \\
\hline $19 X-1,16$ & 167.56 & Uvigerina sp. & 2 & 52.50 & -1.60 & 5.06 \\
\hline $19 X-1,58$ & 167.78 & Uvigerina sp. & 2 & 72.70 & -1.64 & 5.32 \\
\hline $19 X-1,36$ & 167.90 & Uvigerina $\mathrm{sp}$. & 6 & 118.20 & -1.88 & 5.17 \\
\hline $19 X-1,70$ & 168.27 & Uvigerina sp. & 8 & 172.70 & -1.63 & 5.43 \\
\hline $19 \mathrm{X}-2,20$ & 168.77 & Uvigerina $\mathrm{sp}$ & 8 & 179.50 & -1.52 & 5.41 \\
\hline $19 X-2,70$ & 169.04 & Uvigerina $\mathrm{sp}$. & 7 & 179.50 & -1.69 & 5.38 \\
\hline $19 \mathrm{X}-2,120$ & 169.27 & Uvigerina sp. & 2 & 81.80 & -1.43 & 5.31 \\
\hline $19 X-2,97$ & 169.27 & Uvigerina sp. & 2 & 39.40 & -1.57 & 5.24 \\
\hline $19 \mathrm{X}-2,133$ & 169.40 & Uvigerina sp. & 4 & 109.10 & -1.57 & 5.34 \\
\hline $19 \mathrm{X}-2,133$ & 169.40 & Uvigerina sp. & 3 & 86.40 & -1.80 & 5.33 \\
\hline 19X-CC & 169.47 & Uvigerina sp. & 5 & 104.50 & -1.65 & 5.21 \\
\hline 19X-CC & 169.47 & Uvigerina sp. & 4 & 138.10 & -1.54 & 5.16 \\
\hline $20 X-1,51$ & 177.41 & Uvigerina sp. & 4 & 60.90 & -2.21 & 5.31 \\
\hline $20 \mathrm{X}-1,51$ & 177.41 & Uvigerina sp. & 3 & 68.20 & -2.26 & 5.00 \\
\hline \multicolumn{7}{|l|}{ 155-936A- } \\
\hline $42 X-1,67$ & 386.37 & C. wuellerstorfi & 2 & 32.20 & -0.37 & 3.66 \\
\hline $42 \mathrm{X}-1,125$ & 386.95 & C. wuellerstorfi & 2 & 22.70 & -1.97 & 4.71 \\
\hline $42 \mathrm{X}-1,131$ & 387.01 & C. wuellerstorfi & 2 & 14.30 & -1.99 & 4.69 \\
\hline $42 \mathrm{X}-3,99$ & 389.58 & C. wuellerstorfi & 3 & 31.00 & -1.66 & 4.51 \\
\hline $43 X-3,2$ & 397.64 & C. wuellerstorfi (?) & 2 & 48.90 & 0.19 & 3.01 \\
\hline $44 X-1,76$ & 405.76 & C. wuellerstorfi & 4 & 63.60 & -1.24 & 4.44 \\
\hline $44 \mathrm{X}-2,13$ & 406.63 & C. wuellerstorfi & 3 & 46.50 & -0.77 & 3.87 \\
\hline $44 X-2,13$ & 406.63 & C. wuellerstorfi & 2 & 100.00 & -0.81 & 3.99 \\
\hline $44 X-2,81$ & 407.31 & C. wuellerstorfi & 1 & 6.00 & -0.59 & 4.55 \\
\hline $44 \mathrm{X}-2,140$ & 407.90 & C. wuellerstorf $i$ & 2 & 52.50 & -0.70 & 4.25 \\
\hline $44 X-3,11$ & 408.11 & C. wuellerstorfi & 1 & 0.00 & 0.34 & 3.67 \\
\hline $17 X-3,99$ & 149.19 & Uvigerina sp. & 3 & 53.70 & -1.19 & 4.80 \\
\hline $42 X-1,67$ & 386.37 & Uvigerina sp. & 7 & 163.60 & -0.37 & 3.98 \\
\hline $42 X-1,67$ & 386.37 & Uvigerina $\mathrm{sp}$. & 11 & 177.30 & -0.40 & 3.93 \\
\hline $42 \mathrm{X}-1,125$ & 386.95 & Uvigerina sp. & 8 & 159.10 & -1.47 & 4.85 \\
\hline $42 \mathrm{X}-1,125$ & 386.95 & Uvigerina $\mathrm{sp}$. & 13 & 154.50 & -1.35 & 4.69 \\
\hline $42 X-1,131$ & 386.95 & Uvigerina sp. & 13 & 207.10 & -1.28 & 4.77 \\
\hline $42 \mathrm{X}-1,131$ & 387.01 & Uvigerina sp. & 8 & 190.90 & -1.31 & 4.81 \\
\hline $42 X-1,131$ & 387.01 & Uvigerina $\mathrm{sp}$. & 11 & 140.90 & -1.57 & 4.72 \\
\hline $42 X-2,70$ & 387.90 & Uvigerina $\mathrm{sp}$. & 8 & 207.10 & -0.41 & 4.01 \\
\hline $42 X-2,70$ & 387.90 & Uvigerina $\mathrm{sp}$. & 10 & 234.70 & -0.55 & 3.95 \\
\hline $42 X-2,98$ & 388.08 & Uvigerina sp. & 1 & 8.40 & -2.02 & 4.03 \\
\hline $43 X-3,2$ & 397.64 & Uvigerina sp. & 1 & 31.00 & -0.47 & 3.63 \\
\hline $43 X-3,6$ & 397.70 & Uvigerina $\mathrm{sp}$. & 1 & 27.40 & -2.47 & 4.29 \\
\hline $43 X-6,81$ & 402.95 & Uvigerina $\mathrm{sp}$. & 3 & 40.60 & -1.71 & 4.07 \\
\hline $43 X-6,81$ & 402.95 & Uvigerina sp. & 3 & 72.70 & -1.17 & 4.03 \\
\hline $44 X-1,55$ & 405.55 & Uvigerina sp. & 6 & 150.00 & -1.07 & 4.67 \\
\hline $44 X-1,55$ & 405.55 & Uvigerina sp. & 5 & 136.40 & -0.78 & 4.23 \\
\hline $44 X-1,76$ & 405.76 & Uvigerina sp. & 6 & 200.00 & -0.77 & 4.45 \\
\hline $44 X-1,76$ & 405.76 & Uvigerina sp. & 14 & 181.80 & -0.99 & 4.45 \\
\hline $44 X-1,76$ & 405.76 & Uvigerina sp. & 8 & 127.30 & -0.81 & 4.42 \\
\hline $44 \mathrm{X}-1,127$ & 406.27 & Uvigerina sp. & 4 & 95.50 & -0.71 & 4.27 \\
\hline $44 \mathrm{X}-1,127$ & 406.27 & Uvigerina $\mathrm{sp}$. & 4 & 122.70 & -0.33 & 4.31 \\
\hline $44 X-2,13$ & 406.63 & Uvigerina sp. & 5 & 154.50 & -0.39 & 4.08 \\
\hline $44 X-2,13$ & 406.63 & Uvigerina sp. & 13 & 213.60 & -0.43 & 4.06 \\
\hline $44 X-2,54$ & 407.04 & Uvigerina sp. & 9 & 193.30 & -0.62 & 4.17 \\
\hline $44 X-2,54$ & 407.04 & Uvigerina sp. & 8 & 131.80 & -0.52 & 4.17 \\
\hline $44 X-2,81$ & 407.31 & Uvigerina $\mathrm{sp}$. & 5 & 179.50 & -0.48 & 3.95 \\
\hline $44 X-2,81$ & 407.31 & Uvigerina sp. & 13 & 220.90 & -0.54 & 3.91 \\
\hline $44 \mathrm{X}-2,140$ & 407.90 & Uvigerina sp. & 5 & 159.10 & -0.20 & 4.12 \\
\hline $44 \mathrm{X}-2,140$ & 407.90 & Uvigerina sp. & 9 & 122.70 & -0.49 & 4.11 \\
\hline $44 X-3,11$ & 408.11 & Uvigerina sp. & 6 & 109.10 & -0.36 & 3.94 \\
\hline $44 X-3,11$ & 408.11 & Uvigerina sp. & 7 & 163.60 & -0.53 & 4.04 \\
\hline
\end{tabular}




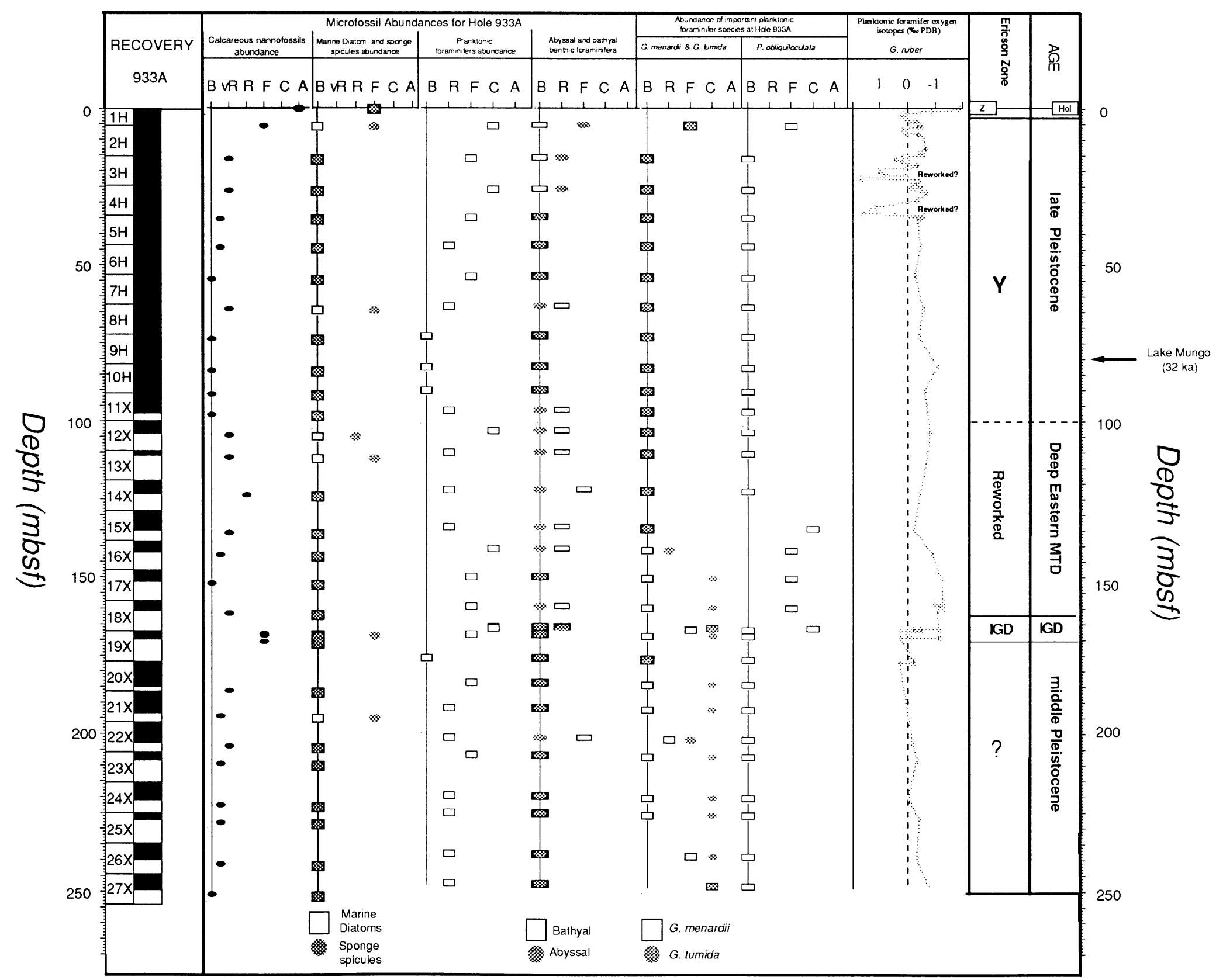




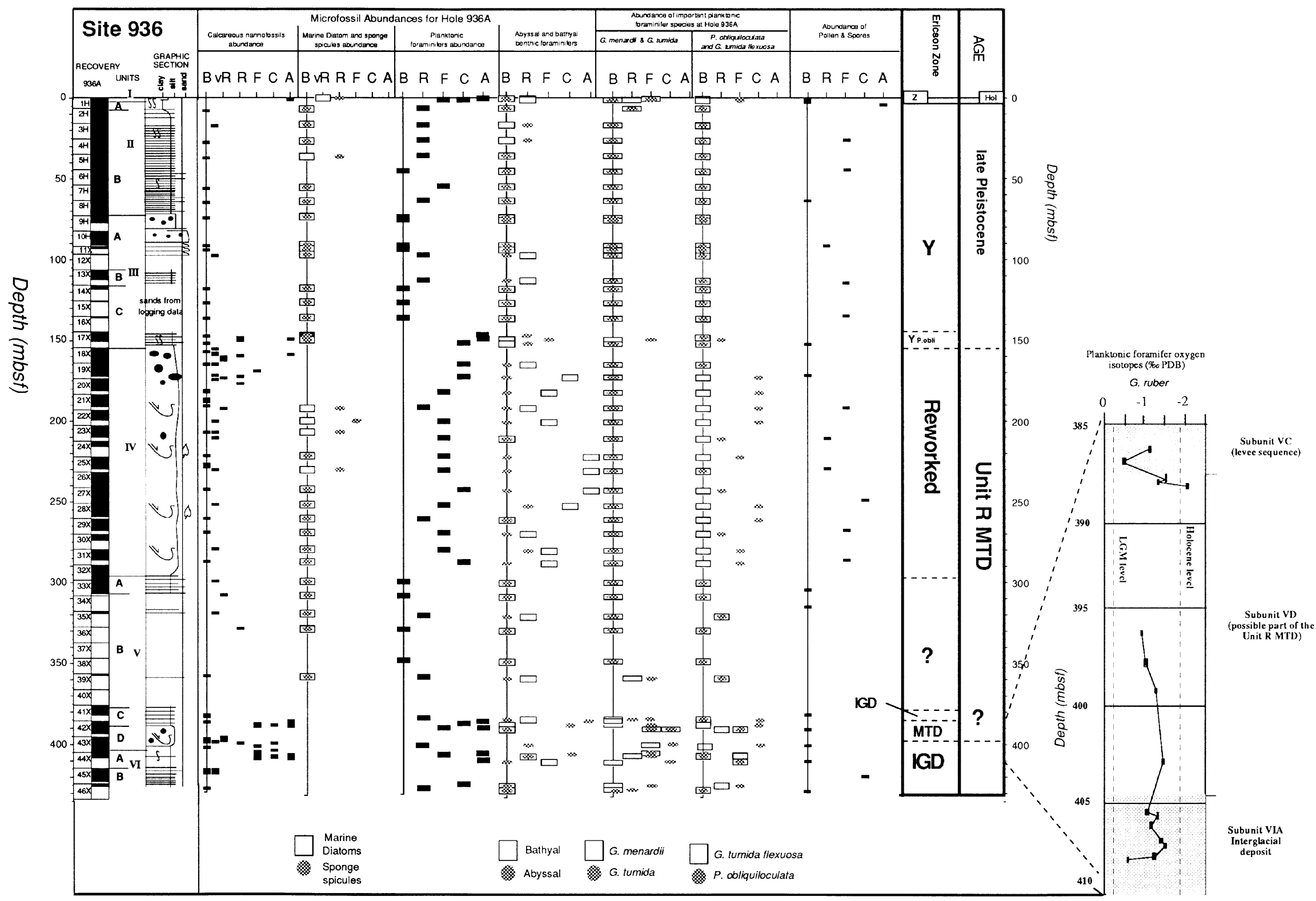


between 40 and $85 \mathrm{ka}$. Only in the case of Site 936 is there hemipelagic mud in contact with the MTD, from which we can suggest that the Unit R MTD was last active between 40 and $85 \mathrm{ka}$. The approximate dating of the tops of both deep MTDs is confirmed by the nannofossil stratigraphy, which indicates that generally, the sediment above the MTDs is from nannofossil Zone CN15b, that is, younger than $85 \mathrm{ka}$ (Maslin and Mikkelsen, this volume).

\section{STABLE ISOTOPE RESULTS}

The oxygen isotope records of planktonic foraminifers in the deep EMTD and the underlying interglacial deposit at Site 933 are shown in Figures 2 and 4. The planktonic foraminifer oxygen isotope results indicate that the interglacial deposit has "lighter" values than the underlying glacial levee muds. However, these values do not generally reach the same level as those of the Holocene. This may indicate either that the deposit represents the very beginning or end of an interglacial period, or that there was reworking of isotopically heavier glacial material into the deposit. Maslin and Mikkelsen (this volume) have suggested that both are likely. Two lines of evidence support this interpretation. First, nannofossil evidence suggests that the interglacial deposits form a condensed sequence. Second, the reworking hypothesis is supported by the benthic foraminifer oxygen isotopes results (Fig. 5), as only glacial values were recorded in the interglacial deposit. It is also important to note that the oxygen isotope values of "reworked" benthic foraminifers are much heavier $(>0.5 \%)$ than those found during the LGM. This indicates either that they originated from a more intense glacial (e.g., oxygen Stage 6) or that they may have been affected by secondary calcification. No evidence of secondary calcification was observed when the specimens were picked; however, many were abraded and of poor quality.

The sparsity of planktonic foraminifers in the deep EMTD meant that only the isotope records of Globigerinoides ruber, G. trilobus, and $N$. dutertrei were possible to measure. These records indicate that the foraminifers in the MTD have oxygen isotope values halfway in between the Holocene and LGM values (Maslin et al., this volume). This indicates that either the sediment from the deep EMTD was formed mainly during early oxygen Stage 3 (or any other early glacial period) when the sea level was still relatively high, or that there is a lot of mixing between interglacial and glacial material within the MTD. The abyssal benthic foraminifers are absent from the deep EMTD, except for the very top, where they gave isotopic values heavier than for the LGM. Again this could be reworking of older material or secondary calcification of the tests.

The sedimentation at Site 936 is more complicated than at Site 933, because of the poor core recovery and the apparent levee mud sequences between the Unit R MTD and the underlying interglacial deposits. In Cores 155-936A-41X through 45X (Fig. 3), a sequence of levee muds overlying a thin MTD was recovered, which in turn, overlies an interglacial deposit on top of more levee muds. What is uncertain is whether the thin MTD is part of the Unit R MTD, despite there being a sequence of levee muds between them. The planktonic foraminifer oxygen isotopes suggest that only the top of Subunit VD (the MTD) has foraminifers that lived during interglacial conditions (Fig. 6). This suggests that the foraminifers in the interglacial deposit are either reworked or that the interglacial deposit was formed during a period when the sea level was not at its maximum height. Moreover, the planktonic foraminifers within the Subunit VD MTD have values very similar to those of the underlying interglacial deposit, indicating reworking of that material into the MTD. The benthic foraminifer oxygen isotope values in all three deposits (Subunits VC, VD, and VIA) are very similar, indicating values similar to those found during the LGM (Fig. 7). This indicates a significant amount of reworking in all three subunits. The only exception is one $C$. wuellerstorfi sample within the Subunit VD MTD, which has an interglacial value. The oxygen isotope record of G. sacculifer in the main Unit R MTD (Showers et al., this volume) again indicates that the sediment was either formed mainly during early oxygen Stage 3 (or any other early glacial period) when the sea level was still relatively high, or that there is much mixing between interglacial and glacial material within the Unit R MTD.

\section{IMPLICATIONS OF THE PLANKTONIC FORAMINIFERAL ASSEMBLAGE AND ISOTOPE DATA}

Unfortunately, the planktonic foraminifer assemblage and the stable isotope records can not help in identifying the origin of the sediment in the MTDs. This is because glacial and interglacial sediments can be found all over the continental slope and the Amazon Fan. They can, however, be used to look at how the MTDs are structured and at the amount of material from various sources that has been picked up and incorporated into the MTDs.

The planktonic foraminifer assemblage and the stable isotope records from Sites 933 and 936 clearly suggest that the MTDs are made up of distinct blocks. This is supported by evidence from the sedimentological (Flood, Piper, Klaus, et al., 1995), physical properties (Long and Manley, this volume), and the water content records. Moreover, the planktonic foraminifer assemblage records suggest that these blocks have different sources of material and occur both in the depth and lateral domain. For example, assemblage and isotope evidence from Sites 933 and 931 suggest that there are three distinct blocks down the deep EMTD sequence that are stacked one on top of another, whereas evidence from Sites 935, 936, and 944 indicate that the same Unit R MTD can have very different blocks of material at different sites across the Fan.

The stable isotope records of the MTDs and the underlying interglacial deposits indicate there was a large amount of reworking of material in and out of each deposit. Maslin and Mikkelsen (this volume) have suggested that the structurally weaker carbonate-rich interglacial deposits may have acted as slip-planes for the MTDs. Therefore, the inclusion of interglacial material at least in the base of the deep MTDs would be expected. Moreover, the foraminifer assemblage and isotope evidence suggests the Amazon Fan deep MTDs contain sediments that were either formed mainly during early oxygen Stage 3 (or any other early glacial period) when the sea level was still relatively high, or that there is a lot of mixing between interglacial and glacial material within the MTD. Evidence from the near surficial Western Debris Flow (Site 941, Maslin and Mikkelsen, this volume) suggests that alternating sources of interglacial and glacial material can occur. However, the key conclusion of these records is that the MTDs incorporate sediment from many different sources and that other tracers such as benthic foraminifers are required to identify them.

\section{BENTHIC FORAMINIFER RESULTS}

Variations in abundance/depth in Holes 933A and 936A can be seen in Figure 8. In Hole 933A there is an increase in number of specimens in the middle of the MTDs interval (131.39 mbsf). The two deepest samples from Hole 933A contained rare and small tests. In Hole 936A, we can see the benthic foraminifer distribution in MTDs, from Cores 155-936A-18X (158.53 mbsf) through 31X (285.58 mbsf). In Hole 936A there is a relatively high number of specimens in the shallowest sample (158.53 mbsf), but numbers decrease with depth and culminate in only rare or no specimens in the last four samples.

Low abundances observed in the samples could have been caused by mass transport and reworking, which are compounded by the 

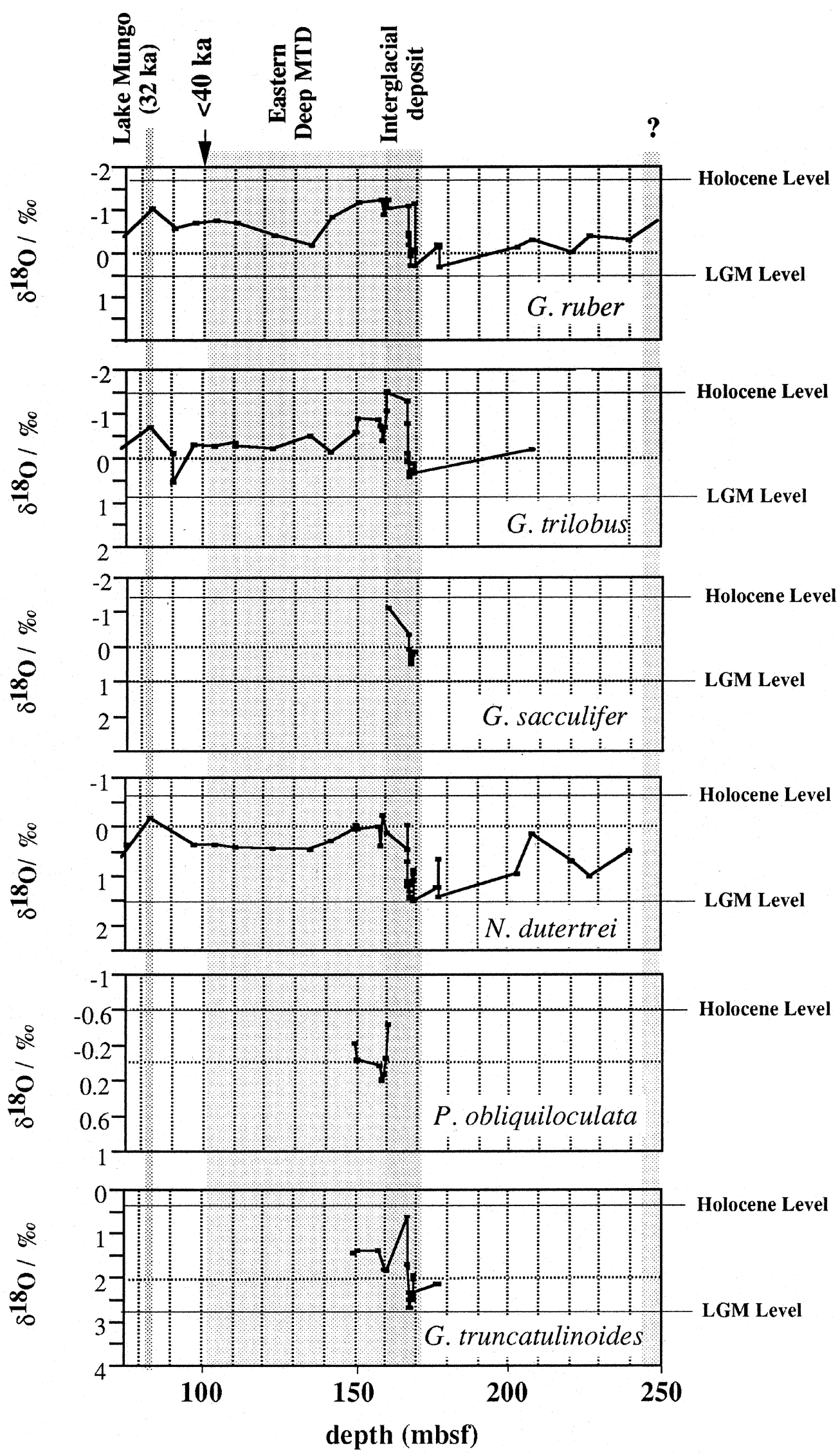

Figure 4. Planktonic foraminifer oxygen isotope records from Site 933. 

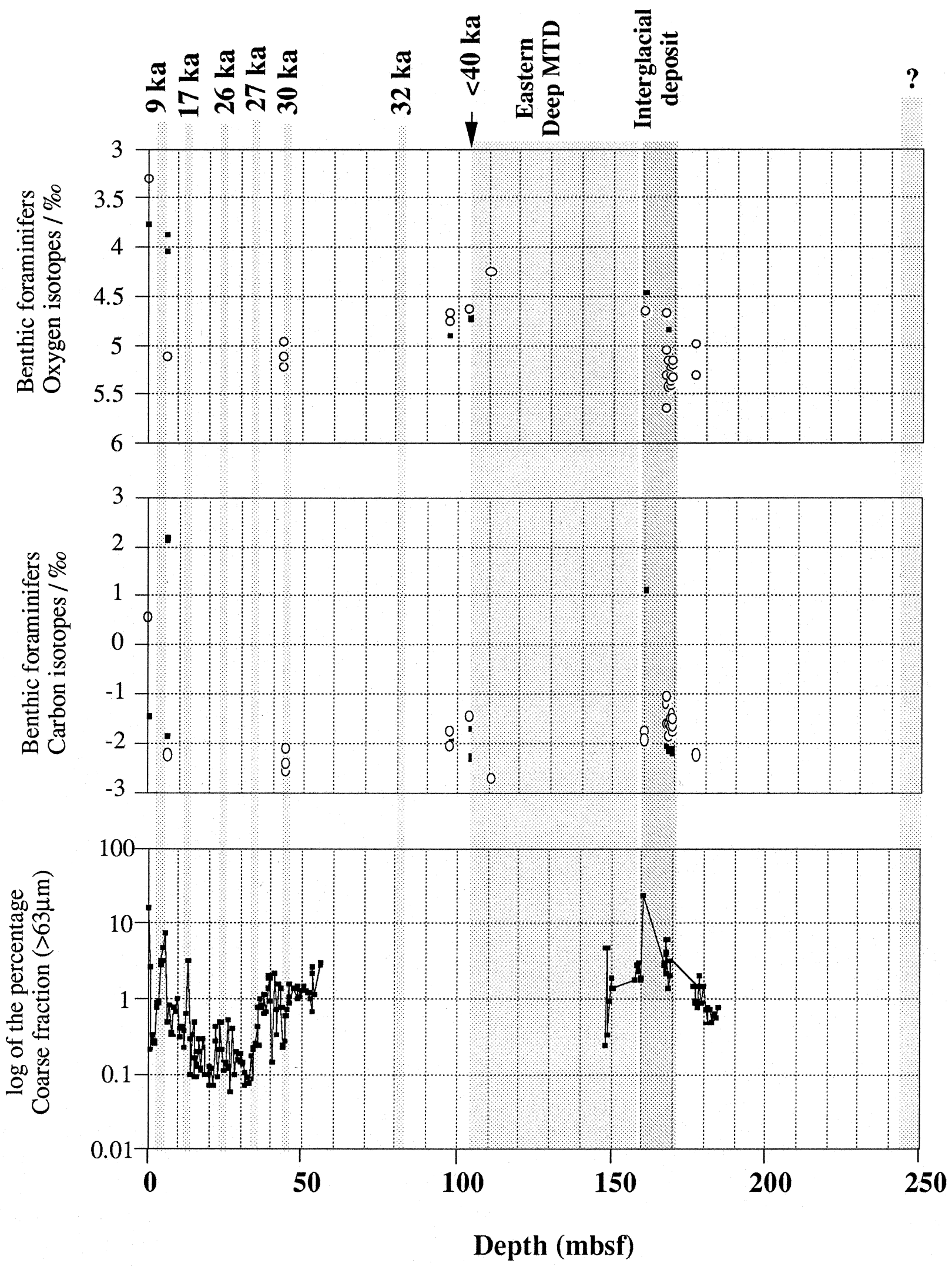

Figure 5. Benthic foraminifer stable isotope records and coarse fraction analysis from Site 933. Solid squares $=$ C. wuellerstorfi, and open circles $=U v i g e r i n a$ sp. 

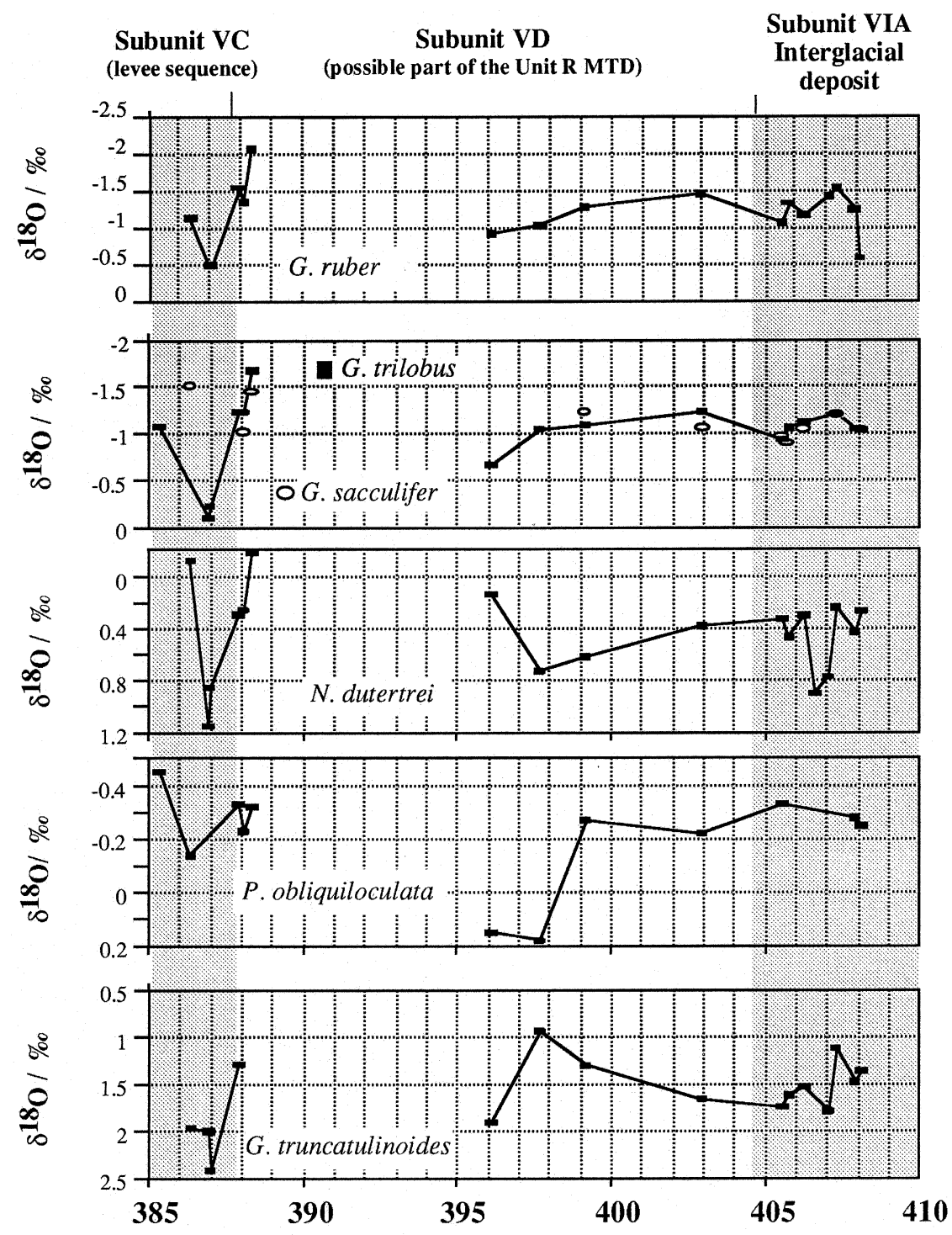

Figure 6. Planktonic foraminifer oxygen isotope records from Site 936.

Depth (mbsf)

small sample volumes $\left(10 \mathrm{~cm}^{3}\right)$ made available for the study. The tests are frequently brown, and many of them are small and abraded, making the taxonomic work difficult.

All the analyzed samples recorded low diversity. The occurrence of selected benthic species can be seen in Table 2. The selected species were chosen for their higher values in the samples but, because the total abundance of the benthics was low, the term "dominant" is not justified. The similarity in the selected species encountered in Holes 933A and 936A can be observed in Table 2. Microfaunal differences between holes are mainly observed in rare and sparse species. The rotaliids predominate in the subsamples, mainly represented by buliminids (e.g., Bulimina cf. gibba, B. aculeata, B. marginata, $B$. costata). Plates 1 and 2 show species encountered in both debris flows. The list of all encountered species in the MTDs can be found in the Appendix.

The different morphotypes observed in benthic foraminifers constitute adaptative responses to modes of life (Koutsoukos and Hart, 1990). Infaunal deposit feeders, like the buliminids, predominate in the samples. Test shapes of the selected species are elongate tapered, globular, or lenticular, and these shapes are assumed to be adaptations to mobility and position within muddy sediments (Corliss and Fois, 1990). These authors found many infaunal taxa in dominance in the continental slope of the Mississippi Fan. Low oxygen-related assemblages, dominated by buliminids, were found on the northeast United States continental slope (Miller and Lohmann, 1982). Bathymetric zonation of modern benthic foraminifers characterized the distribution of several species, including species of Bulimina, in the northwestern Gulf of Mexico Slope (Lagoe et al., 1994). The above characteristics suggest a continental-slope origin for most of the MTDs. Cassidulina and Quinqueloculina, which are also present in the MTDs, are epifaunal to shallow infaunal deposit feeders, the latter possibly transported from shelf settings. Agglutinated tests, indicative of deeper environments, were not present in the subsamples; nevertheless, some existing tests could have been destroyed during the mass transport.

\section{COMPARISONS WITH BENTHIC FORAMINIFERS FROM THE SHELF, SLOPE, AND ABYSSAL SETTINGS}

Studies based on the Holocene benthic foraminiferal microfauna were developed with samples collected in the Amazon shelf and slope. The Amazon shelf samples were available for study as part of 


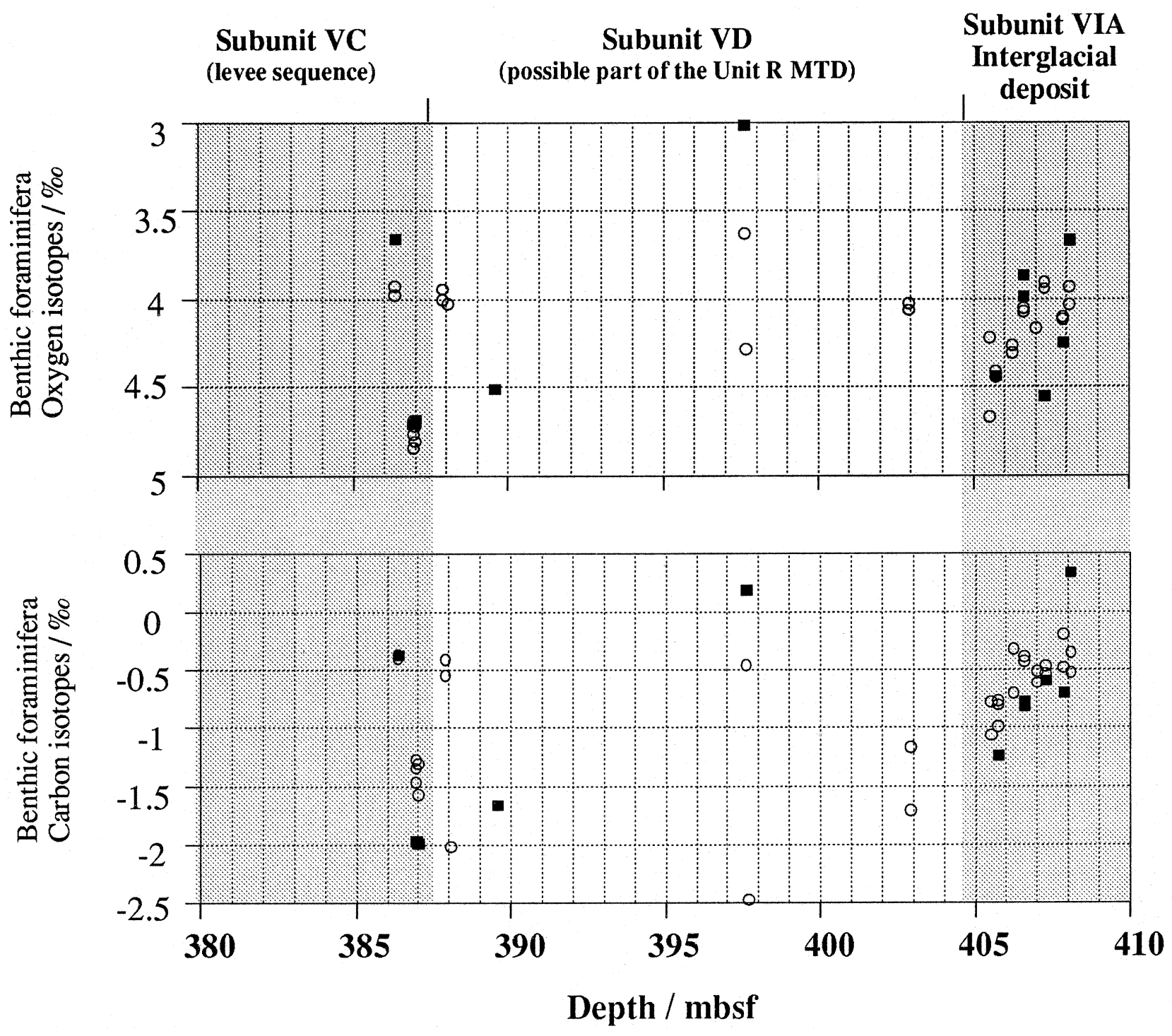

Figure 7. Benthic foraminifer stable isotope records from Site 936. Solid squares $=$ C. wuellerstorfi, and open circles $=$ Uvigerina $\mathrm{sp}$.

the AmasSeds Project, "A Multidisciplinary Amazon Shelf Sediment Study" (Nittrouer et al., 1991). The analyzed subsamples were from five piston-cores collected in the strike section, in the middle and outer shelf in front of the Amazon coast, as well as eight box-cores collected in two transects that cross the inner, middle, and outer parts of the Amazon shelf (Fig. 9). The assemblages show ecological patterns related to the Amazon River discharge (Vilela, 1995). The abundant and small benthic tests in the middle and outer shelf presented mainly plano-convex and low trochospiral morphotypes. These morphotypes are epifaunal deposit-feeders, according to Corliss and Fois (1990). In the Amazon shelf they are represented by the following dominant species: Ammonia beccarii, Stetsonia minuta, Cibicides refulgens, Pseudononion atlanticum, and Fursenkoina pontoni. Elongate tapered, compressed specimens characterize a distinct infaunal microhabitat and they are well represented by Brizalina semicarinata and Fursenkoina pontoni. A distinct assemblage encountered in relict sediments shows distinct characteristics of a shallower shelf environment. The dominant species are Quinqueloculina lamarckiana, Quinqueloculina bicostata, and Amphistegina lessonii, with larger tests (Vilela, 1995).

Species like Quinqueloculina lamarckiana, Quinqueloculina sp. $\mathrm{A}$, and $P$. atlanticum, which are present on the shelf, were encountered in the MTDs. The shelf B. semicarinata and the debris-flow Bo- livina aenariensis have the same morphotype, as well as the shelf $F$. pontoni and the debris flow Stainforthia complanata. B. aenariensis differs only in the test shape, which has a more acute tapered form and more acute ridges (Plates 1,2).

On the Amazon continental slope, samples collected by two piston-cores at upper $(382 \mathrm{~m})$ and middle $(910 \mathrm{~m})$ bathyal depths were analyzed (Fig. 9). They were collected as part of the Geomar II Project ("XLVI Comissão Oceanográfica-Operação Geomar II, Costa Norte/Geologia Marinha"), from Marinha do Brasil, Hidrografia e Navegação (Santos, 1972). Studies carried out (C.G. Vilela, unpubl. data) show that Globocassidulina subglobosa is a dominant species in the upper and middle bathyal, and was also encountered in the MTDs, although it was rare (Plate 2). Cassidulina laevigata is common on the upper slope and is also encountered in the MTDs (Plate 1). Buliminids (e.g., Bulimina marginata, B. aculeata, B. cf gibba and B. costata), which are common in the upper and middle slope, were commonly found in the MTDs (Plates 1 and 2).

The Amazon shelf and slope data from the Holocene can provide a model for comparative studies with the mass-transport assemblages. The analyzed MTDs should have been deposited many thousands of years before, in the late Pleistocene, and this fact could likely cause some differences at the species level. However, the general morphotypes and morphogroups of the benthic microfauna can still be con- 
933 A

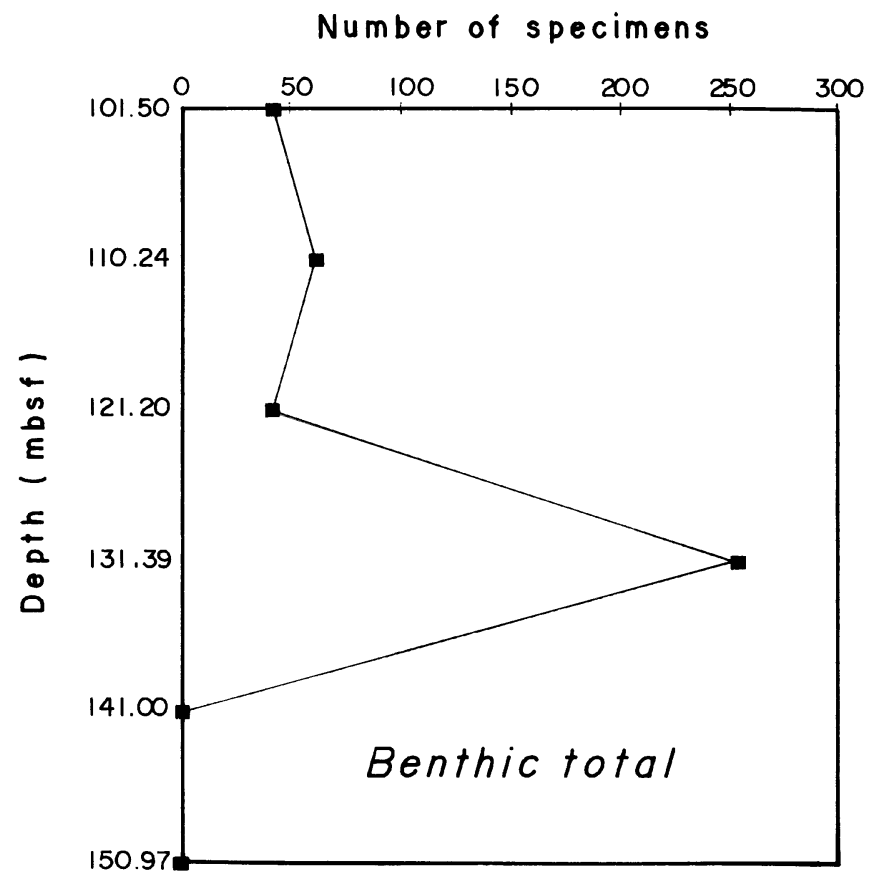

936 A

Number of specimens

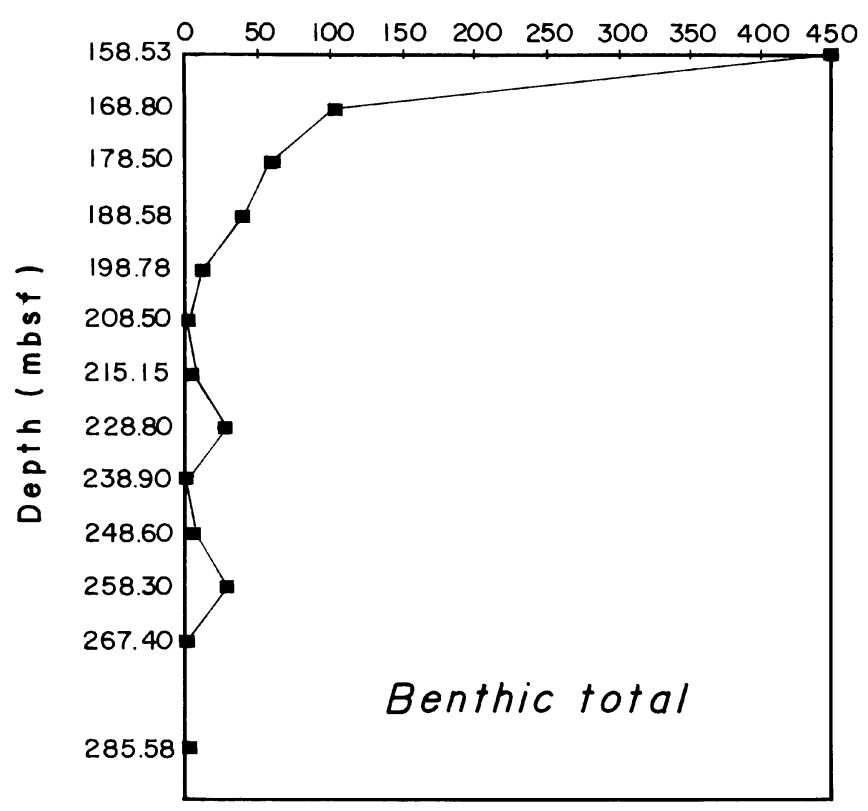

Figure 8. Abundances of benthic foraminifers in Holes 933A and 936A.

Table 2. Total number of benthic foraminifers, number of species, and specimens of selected species (dominant) per sample in Holes 933A and 936A.

\begin{tabular}{|c|c|c|c|c|c|c|c|c|c|c|}
\hline $\begin{array}{l}\text { Core, section, } \\
\text { interval }(\mathrm{cm})\end{array}$ & $\begin{array}{l}\text { Depth } \\
\text { (mbsf) }\end{array}$ & $\begin{array}{c}\text { Benthic } \\
\text { total }\end{array}$ & $\begin{array}{l}\text { N. of } \\
\text { species }\end{array}$ & Brae. & C.lae. & Bu.g. & Bu.ac. & Bu.ma & St.co. & $Q \cdot \operatorname{spA}$ \\
\hline \multicolumn{11}{|l|}{ 155-933A- } \\
\hline $12 X-2,20-25$ & 101.50 & 42 & 13 & 4 & 2 & 1 & 4 & 1 & 1 & - \\
\hline $13 \mathrm{X}-1,84-88$ & 110.24 & 61 & 15 & 15 & 8 & 4 & - & - & - & 5 \\
\hline $14 X-2,70-75$ & 121.20 & 41 & 13 & 13 & 6 & 1 & - & - & 1 & 9 \\
\hline $15 X-2,119-124$ & 131.39 & 253 & 23 & 26 & 35 & 27 & 10 & 17 & 13 & 4 \\
\hline $16 \mathrm{X}-2,120-125$ & 141.00 & - & - & - & - & - & - & - & - & - \\
\hline $17 X-3,7-12$ & 150.97 & 3 & 2 & - & - & - & - & - & - & - \\
\hline \multicolumn{11}{|l|}{ 155-936A- } \\
\hline $18 X-3,103-107$ & 158.53 & 448 & 19 & 108 & 92 & 24 & 48 & 12 & 28 & - \\
\hline $19 X-4,20-25$ & 168.80 & 104 & 9 & 8 & - & - & 28 & - & 8 & - \\
\hline $20 X-4,20-25$ & 178.50 & 60 & 6 & - & - & - & 16 & - & - & - \\
\hline $21 X-5,68-73$ & 188.58 & 40 & 4 & - & 8 & - & 8 & - & 8 & - \\
\hline $22 \mathrm{X}-4,118-123$ & 198.78 & 11 & 5 & - & - & - & - & - & 1 & - \\
\hline $23 X-4,120-125$ & 208.50 & 1 & 1 & - & - & 1 & - & - & - & - \\
\hline $24 \mathrm{X}-2,115-120$ & 215.15 & 6 & 4 & - & - & - & - & - & - & - \\
\hline $25 X-5,70-75$ & 228.80 & 28 & 3 & - & - & - & 1 & - & 25 & - \\
\hline $26 \mathrm{X}-5,120-125$ & 238.90 & 1 & 1 & - & - & - & - & - & - & - \\
\hline $27 X-5,120-125$ & 248.60 & 7 & 3 & - & - & 2 & - & - & 4 & - \\
\hline $28 \mathrm{X}-5,120-125$ & 258.30 & 29 & 12 & 4 & 1 & 1 & 7 & 1 & 1 & - \\
\hline $29 X-5,70-75$ & 267.40 & - & - & - & - & - & - & - & - & - \\
\hline $31 X-4,118-122$ & 285.58 & 3 & 2 & - & - & - & - & 1 & - & - \\
\hline $32 X-5,121-126$ & 295.11 & - & - & - & - & - & - & - & - & - \\
\hline $43 X-2,20-25$ & 396.34 & - & - & - & - & - & - & - & - & - \\
\hline
\end{tabular}

Notes: $-=$ no occurrence. Br.ae. $=$ Brizalina aenariensis; C.lae. $=$ Cassidulina laevigata $;$ Bu.g. $=$ Bulimina $\mathrm{cf}$. gibba $;$ Bu.ac = B. aculeata Bu.ma $=$ B. marginata $;$ St.co. $=$ Stainforthia complanata; $Q \cdot \operatorname{sp} A=$ Quinqueloculina $\mathrm{sp}$ A.

sidered. Epifaunal/shallow-infaunal deposit feeders like cassidulinids, and infaunal taxa like buliminids, are bathyal forms found in the Amazon continental slope and were commonly encountered in the MTDs. Quinqueloculina sp. A and P. atlanticum are shelf species found in the MTDs. The shelf infaunal dominant species B. semicarinata and $F$. pontoni can be compared with the mass-transport species B. aenariensis and S. complanata. According to Sgarrella (1992), Brizalina aenariensis is a paleoclimatic indicator, being abundant during cold intervals of the Pleistocene in sediments of the Mediterranean.
Analyses of the top centimeters ( $0.21 \mathrm{mbsf})$ and at $5.90 \mathrm{mbsf}$ were carried out in Hole 933A to make a microfauna evaluation of in situ Amazon Fan sediments that do not belong to the MTDs. They are Holocene pelagic sediments and LGM hemipelagic sediments, respectively. These sediments were, at present, from $\sim 3300 \mathrm{~m}$ of water depth. The oxygen isotopes confirm that the sediments at $0.21 \mathrm{mbsf}$ are Holocene. At $5.90 \mathrm{mbsf}$, according to the paleomagnetic age model, the sediments are between 14 and $17 \mathrm{ka}$.

The Holocene pelagic sediments are formed by calcareous clay with numerous large planktonic foraminifers. We found rare calcare- 


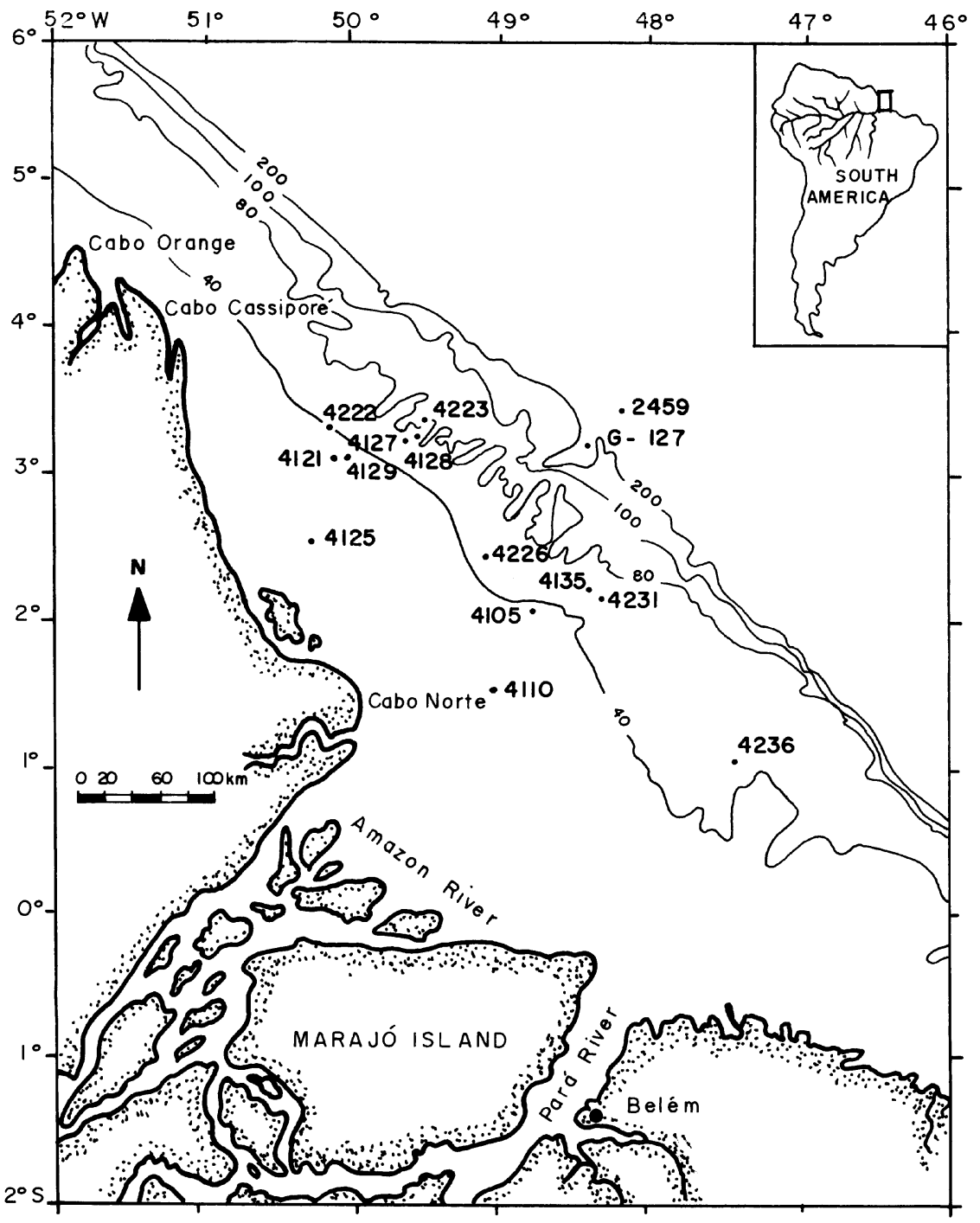

Figure 9. Analyzed box-cores and piston-cores from the Amazon shelf and slope. Box-cores: 4105, 4110, 4135, 4121, 4125, 4127, 4128, 4129. Piston-cores: 4222, 4223, 4226, 4231, 4236, G-127, 2459. ous benthic specimens (e.g., C. wuellerstorfi and Laticarinina pauperata) and some large fragments of tubular shaped agglutinated foraminifer morphotypes (e.g., Bathysiphon spp.). These agglutinated specimens are usually associated with gravity flow deposits in the middle-lower bathyal and abyssal settings (Berggren, 1984; Winkler, 1984).

The LGM sediments originated at shallower depths than the Holocene sediments, due to the last glacial sea regression. They are formed by silty mud dominated by planktonic foraminifers, with rare and abraded benthic tests that make the correct classification at species level difficult. Both the planktonic and benthic tests are brown. This microfauna is associated with echinoid spines and plates. The mechanical dissolution of the tests may be caused by the dynamics of the sediments. In glacial periods of the Pleistocene, the Amazon River crossed the shelf and discharged directly into deep water and onto the fan (Damuth and Kumar, 1975). The different assemblages found in both abyssal and MTDs demonstrate a distinct origin for the MTDs.

Figure 10 summarizes the distribution of Holocene benthic foraminiferal species related to depth habitat. The species are dominant in their habitats, except Quinqueloculina sp. A. The figure also shows the occurrence of selected species in the MTDs. We can observe the presence of shelf and slope species in both MTDs.

In the deep EMTD unit of Hole 933A, two distinct bathymetric settings are suggested. The Bulimina-dominated assemblage sug- gests an upper/middle bathyal environment, whereas samples that include several specimens of B. aenariensis, S. complanata, and Quinqueloculina sp. A suggest a source from shelf settings.

In the upper part of Unit R of Hole 936A, where the number of specimens is significant, the pattern is similar. B. aenariensis dominates in the top of the unit, whereas the Bulimina assemblage decreases slightly.

\section{CONCLUSIONS}

The foraminifer assemblage and isotope evidence suggest that the majority of the MTDs contain sediments either formed during early oxygen Stage 3 (or another early glacial period), or that there is a significant mixing between interglacial and glacial material within the separate mass-transport deposit blocks.

All studied samples in the MTDs show low abundance and diversity of the benthic foraminifers. Abundance is highest in the middle of the MTD, at $131.39 \mathrm{mbsf}$ in Hole 933A, and at the top of the unit, at $158.53 \mathrm{mbsf}$ in Hole 936A. The absence of agglutinated tests suggests that the MTDs originated from environments shallower than middle bathyal. The overall dominance of buliminids suggests that the mass-transport deposits originated from the continental slope (upper and middle bathyal environments). The presence of Brizalina aenariensis, Stainforthia complanata, and/or Quinqueloculina sp. A to 


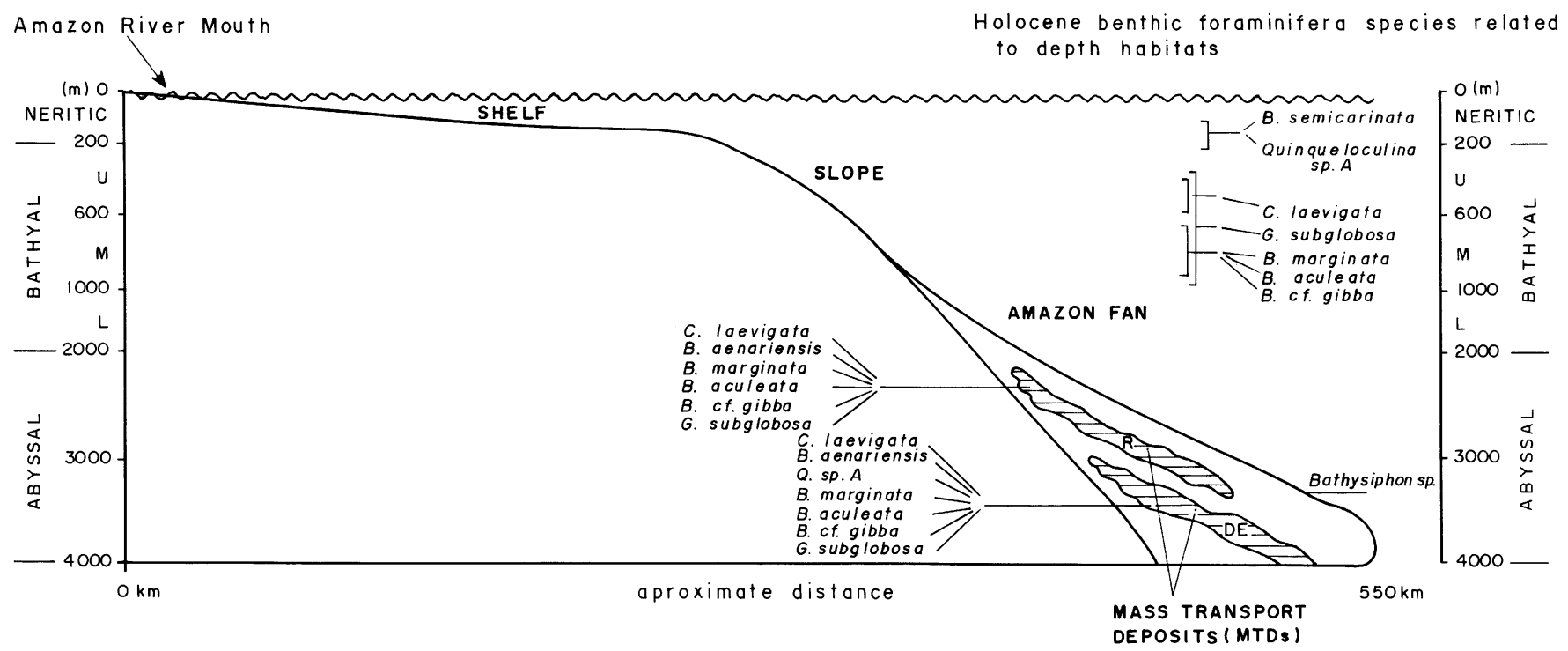

Figure 10. Recent benthic foraminifer species related to depth habitats. Occurrence in mass-transport deposits. R = Unit R Mass-transport Deposit; DE = Deep Eastern Mass-transport Deposit.

the point of dominance in certain intervals indicates a source from the continental shelf.

\section{ACKNOWLEDGMENTS}

This study was supported by the Deutsche Forschungsgemeinschaft and the Conselho Nacional de Desenvolvimento Científico e Tecnológico, from Brazil. Mark Maslin would like to thank Deutsche Forschungsgemeinschaft and the Department of Geography (UCL) for funding and support.

The authors thank the Ocean Drilling Program for the opportunity to participate and analyze the samples from Leg 155 . We also thank the Federal University of Rio de Janeiro, where the study was conducted, and Petróleo Brasileiro S.A., for the SEM photomicrographs. We specially thank Dr. Renato Kowsmann (Cenpes, Petróleo Brasileiro S.A.) for his great help and important suggestions. Thanks are also given to Dr. William Showers (North Carolina State University), Dr. Eduardo Koutsoukos (Cenpes, Petróleo Brasileiro S.A.), and the reviewers of the manuscript.

\section{REFERENCES}

Berggren, W.A., 1984. Cenozoic deep water benthic foraminifera: a review of major developments since Benthonics '75. Benthos i83, 2nd Int. Symp. on Benthic Foraminifera (Pau, April 1983), 41-43.

Corliss, B.H., and Fois, E., 1990. Morphotype analysis of deep-sea benthic foraminifera from the Northwest Gulf of Mexico. Palaios, 5:589-605.

Damuth, J.E., Flood, R.D., Kowsmann, R.O., Belderson, R.H., and Gorini, M.A., 1988. Anatomy and growth pattern of Amazon deep-sea fan as revealed by long-range side-scan sonar (GLORIA) and high-resolution seismic studies. AAPG Bull., 72:885-911.

Damuth, J.E., and Embley, R.W., 1981. Mass-transport processes on the Amazon Cone: western equatorial Atlantic. AAPG Bull., 65:629-643.

Damuth, J.E., and Kumar, N., 1975. Amazon Cone: morphology, sediments, age, and growth pattern. Geol. Soc. Am. Bull., 86:863-878.

Ericson, D.B., and Wollin, G., 1956. Micropaleontological and isotopic determinations of Pleistocene climates. Micropaleontology, 2:257-270.

Ericson, D.B., and Wollin, G., 1968. Pleistocene climates and chronology in deep-sea sediments. Science, 162:1227-1234.

Ericson, D.B., Ewing, M., Wollin, G., and Heezen, B.C., 1961. Atlantic deepsea sediment cores. Geol. Soc. Am. Bull., 72:193-286.
Flood, R.D., Piper, D.J.W., and Shipboard Scientific Party, 1995. Introduction. In Flood, R.D., Piper, D.J.W., Klaus, A., et al., Proc. ODP, Init. Repts., 155: College Station, TX (Ocean Drilling Program), 5-16.

Hoorn, C., Guerrero, J., Sarmiento, G.A., and Lorente, M.A., 1995. Andean tectonics as a cause for changing drainage patterns in Miocene northern South America. Geology, 23:237-240.

Koutsoukos, E.A.M., and Hart, M.B., 1990. Cretaceous foraminiferal morphogroup distribution patterns, palaeocommunities and trophic structures: a case study from the Sergipe Basin, Brazil. Trans. R. Soc. Edinburgh: Earth Sci., 81:221-246.

Lagoe, M.B., Gary, A.C., Zellers, S., Sloan, B., Noble, P., and Johns, R. 1994. Bathymetric zonation and relationship to sea-bed environments of modern benthic foraminiferal biofacies, northwestern Gulf of Mexico slope. Trans. Gulf Coast Assoc. Geol. Soc., 44:355-364.

Loeblich, A.R. and Tappan, H., 1988. Foraminiferal Genera and Their Classification: New York (Van Rostrand Reinhold).

Manley, P.L., and Flood, R.D., 1988. Cyclic sediment deposition within the Amazon deep-sea fan. AAPG Bull., 72:912-925.

Miller, K.G., and Lohmann, G.P., 1982. Environmental distribution of Recent benthic foraminifera on the northeast United States continental slope. Geol. Soc. Amer. Bull., 93:200-206.

Nittrouer, C.A., Demaster, D.J., Figueiredo, A.G. and Rine, J.M., 1991. AmasSeds: an interdisciplinary investigation of a complex coastal environment. Oceanography, 4:3-7.

Santos, M.E.M., 1972. Paleogeografia do Quaternário superior na plataforma continental norte brasileira. Anais, 2:267-288.

Sgarrella, F., 1992. Revision of Brizalina aenariensis Costa, 1856 (Foraminiferida). Boll. Soc. Paleontol. Ital., 31:317-323.

Trauth, M., 1995. Bioturbate Signalverzerrung hockauflosender pal\%oozeanographischer Zeitreihen (Bioturbational signal distortion of high-resolution paleoceanographic time-series) [Ph.D. thesis]. Geol.Paleaontol. Inst., Univ. Kiel.

Vilela, C.G., 1995. Ecology of Quaternary benthic foraminiferal assemblages on the Amazon shelf, northern Brazil. Geo-Mar. Lett., 15:199-203.

Winkler, W., 1984. Rhabdammina-fauna: what relation to turbidites? Evidence from the Gurnigel-Schlieren Flysch. In Oertli, H.J. (Ed.), Benthos i83, 2nd Int. Symp. on Benthic Foraminifera (Pau, April 1983), 611-617.

Date of initial receipt: 11 December 1995

Date of acceptance: 28 May 1996

Ms 155SR-219 


\section{APPENDIX}

In the analyzed samples from the MTDs, 42 species of benthic foraminifera were encountered and all are listed below. Many of the them occur rarely, sometimes even represented by only one specimen. The rank of species in the list is according to the genera rank in Loeblich and Tappan (1988). The undetermined species are small or abraded, making the precise species identification difficult.

Spirillina vivipara Ehrenberg

Quinqueloculina lamarckiana d'Orbigny

Quinqueloculina cf. seminulum (Linnaeus)

Quinqueloculina sp. A

Quinqueloculina spp.

Triloculina trigonula (Lamarck)

Nummoloculina irregularis (d'Orbigny)

Nodosaria sp. indet.

Lenticulina sp. indet.

Lagena sp. indet.

Oolina sp. indet.

Fissurina marginata (Montagu)

Fissurina sp. indet.

Bolivina subexcavata Cushman and Wickenden

Bolivina spp.

Brizalina aenariensis O.G. Costa

Bolivinellina translucens (Phleger and Parker)
Cassidulina laevigata d'Orbigny

Cassidulina sp.

Globocassidulina subglobosa (Brady)

Islandiella cf. australis (Phleger and Parker)

Islandiella sp. indet.

Stainforthia complanata (Egger)

Bulimina marginata d'Orbigny

Bulimina aculeata d'Orbigny

Bulimina cf. gibba Fornasini

Bulimina elongata d'Orbigny

Bulimina costata d'Orbigny

Bulimina striata d'Orbigny

Globobulimina cf. pacifica Cushman

Uvigerina peregrina Cushman

Uvigerina sp.

Eponides antillarum (d'Orbigny)

Eponides sp. indet.

Discorbis candeiana (d'Orbigny)

Cibicides refulgens de Monfort

Nonion pompilioides (Flichtel and Moll)

Nonionella opima Cushman

Nonionella sp. indet.

Pseudononion atlanticum (Cushman)

Pseudononion cuevanensis Saunders and Muller-Merz

Pseudononion sp. indet.

Alabamina sp. indet. 

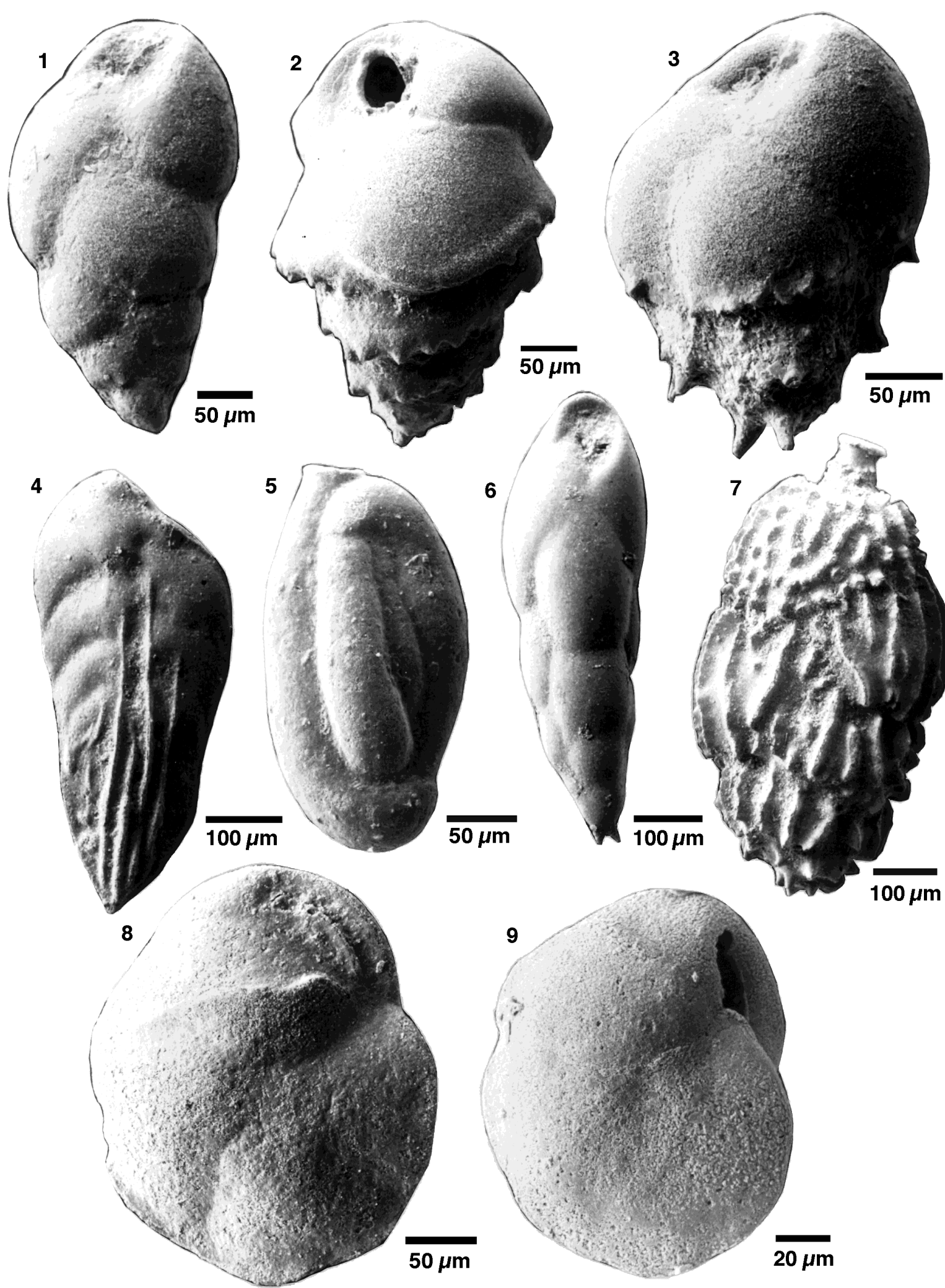

Plate 1. SEM photomicrographs. 1. Bulimina cf. gibba. Front view. Sample 155-933A-15X-2, 131.39 mbsf. 2. B. marginata. Front view. Sample 155-933A15X-2, 131.39 mbsf. 3. B. aculeata. Front view. Sample 155-933A-15X-2, 131.39 mbsf. 4. Brizalina aenariensis. Front view. Sample 155-933A-13X-1, 110.24 mbsf. 5. Quinqueloculina sp. A. Front view. Sample 155-933A-14X-2, 121.20 mbsf. 6. Stainforthia complanata Front view. Sample 155-933A-12X-2, 101.50 mbsf. 7. Uvigerina peregrina. Front view. Sample 155-936A-18X-3, 158.53 mbsf. 8. Cassidulina laevigata. Front view. Sample 155-933A-13X-1, 110.24 mbsf. 9. Cassidulina sp. Front view. Sample 155-933A-12X-2, 101.50 mbsf. 


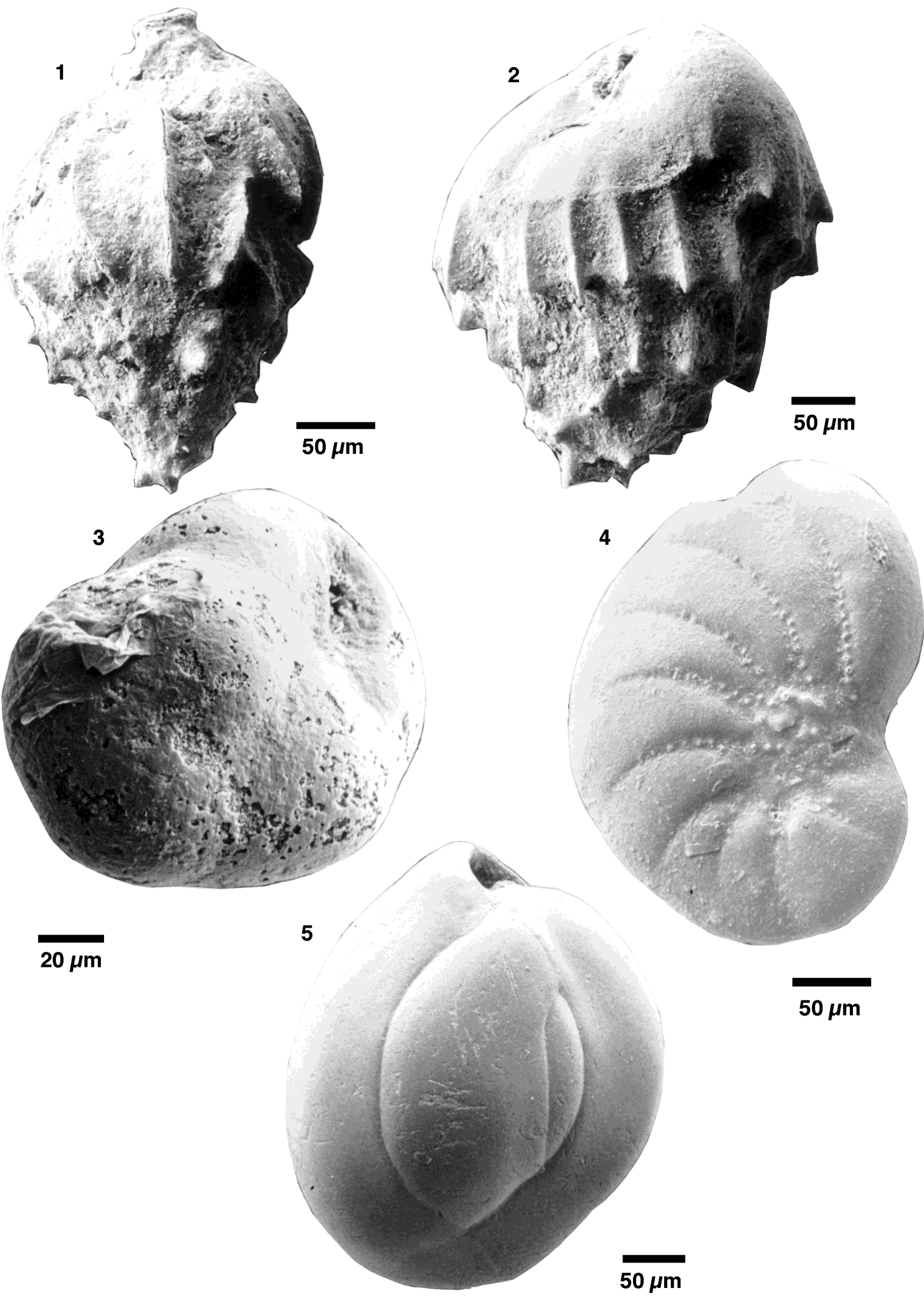

Plate 2. SEM photomicrographs. 1. Uvigerina sp. Front view. Sample 155-936A-18X-3, 158.53 mbsf. 2. Bulimina bicostata. Front view. Sample 155-936A18X-3, 158.53 mbsf. 3. Globocassidulina subglobosa. Front view. Sample 155-933A-12X-2, 101.50 mbsf. 4. Pseudononion atlanticum. Front view. Sample 155-936A-18X-3, 158.53 mbsf. 5. Quinqueloculina lamarckiana. Front view. Sample 155-936A-19X-4, 168.80 mbsf. 